\title{
Detection of induced death of embryos in sheep by the rosette inhibition test
}

\author{
C. D. Nancarrow, B. M. Evison, R. J. Scaramuzzi and K. E. Turnbull \\ C.S.I.R.O., Division of Animal Production, P.O. Box 239, Blacktown, New South Wales, 2148, \\ Australia
}

\begin{abstract}
Summary. The rosette inhibition test has been used to monitor the decrease of an 'early pregnancy factor' in 2 groups of pregnant sheep (19-21 days) in which embryos were removed surgically or by induction of luteolysis with cloprostenol. The rosette inhibition titres of sera taken from sheep of each group declined from high (16-18) to low (8-10) levels within $48 \mathrm{~h}$ of treatment. Surgical removal of embryos caused little change in serum progesterone concentration whereas cloprostenol prompted a rapid decrease over the same period. Death of the embryo can therefore be detected by the rosette inhibition test within $48 \mathrm{~h}$ of occurrence, but not necessarily by the measurement of progesterone in blood within this period.
\end{abstract}

\section{Introduction}

The problem of embryo mortality in sheep has long been recognized (see reviews by Edey, 1969, 1976). Unfortunately, quantitation of this problem requires slaughter of subsamples of animals which precludes direct comparisons of fertilization and continued pregnancy for individuals. Therefore, an improved understanding of the causes and reproductive effects of early embryo mortality must await an accurate and fast diagnosis for fertilization and early pregnancy.

With this need in mind, it was decided to investigate further the rosette inhibition test which has been adapted by Morton, Nancarrow, Scaramuzzi, Evison \& Clunie (1979) to detect an 'early pregnancy factor' in serum of sheep between 1 and 21 days after mating. This factor augments the immunosuppressive action of an antiserum to sheep lymphocytes which can inhibit the number of spontaneous rosettes formed between ovine lymphocytes and human red blood cells (RBC). Morton et al. (1979) described 1 animal in which the 'early pregnancy factor' was detectable for only the first 6 days after mating and the ewe returned to oestrus on Day 19. This was interpreted as serological evidence of early embryo mortality and suggests that the rosette inhibition test could indicate not only continuation of pregnancy but also death of embryos, at least within the first 21 days after mating.

In the present study we have examined this possibility by monitoring the disappearance of 'early pregnancy factor' following embryo death caused by surgical interference or by induction of luteolysis with a prostaglandin.

\section{Materials and Methods}

Merino ewes were injected i.m. with $125 \mu \mathrm{g}$ of an analogue of prostaglandin F-2 $\alpha$, cloprostenol (Estrumate: I.C.I., Australia), and kept with 2 intact Merino rams bearing raddle harnesses. Twice each day ewes with fresh raddle markings were noted until 4 days after cloprostenol treatment when the rams were replaced with other vasectomized rams. Further raddle marks were noted daily for another 17 days. 


\section{Experiment 1}

Four (4) ewes that did not return to oestrus were selected as pregnant, 2 at 19 days and 2 at 20 days post coitum. Anaesthesia was induced with i.v. injection of $12 \mathrm{ml} 5 \%$ sodium thiopentone (Pentothal: Abbott Laboratories) and maintained with halothane (Fluothane: I.C.I., Australia). The uterus was exposed via mid-line laparotomy and a $2-\mathrm{cm}$ incision was made longitudinally in the antimesometrial side of the pregnant horn. The embryo and most, if not all, of the membranes were removed by forceps and the incision was closed with surgical catgut (4/0 Metric 2). The laparotomy incisions were stitched and the ewes allowed to recover.

Samples of jugular venous blood were collected by venepuncture into $5 \mathrm{ml}$ silicone-coated tubes (Vacutainer: Becton-Dickinson, New Jersey) before and at 1, 2, 4, 6, 8, 24 and $48 \mathrm{~h}$ after surgery. An aliquot of the separated serum was stored at $-10^{\circ} \mathrm{C}$ until assayed for progesterone and the remainder was complement-inactivated by heating at $56^{\circ} \mathrm{C}$ for $30 \mathrm{~min}$ then stored at $-30^{\circ} \mathrm{C}$ until application of the rosette inhibition test.

\section{Experiment 2}

Six (6) of the pregnant ewes were selected and re-injected on Days 19-21 with $125 \mu \mathrm{g}$ cioprostenol to induce luteolysis (Hearnshaw, Restall, Nancarrow \& Mattner, 1974), thus causing resorption or abortion of the embryos by removal of the source of progesterone. Blood was collected at the time of cloprostenol injection and 24 (4 ewes) and $48 \mathrm{~h}$ later. It was processed as above.

\section{Progesterone assay}

Progesterone was measured in duplicate $0.5 \mathrm{ml}$ samples by the competitive protein-binding method described by Bassett \& Hinks (1969) and modified by Thorburn \& Schneider (1972). The quoted figures have not been corrected for recovery (79-89\%) and the sensitivity of the assay, defined as twice the s.d. of the blank values, was $0.2 \mathrm{ng} / \mathrm{ml}$. The within-assay coefficient of variation was $<18 \%$ over the range of $1-8 \mathrm{ng} / \mathrm{ml}$. Because of low yields of serum, progesterone was not measured in some samples.

\section{Rosette inhibition test}

The preparation of antilymphocyte serum, spleen cell suspension, guinea-pig serum (complement) and human RBC suspension, and the methodology of the rosette inhibition test have been described in detail by Morton et al. (1979). It is a modification of the test of Bach, Dormont, Dardenne \& Balner (1969). Briefly, a sheep spleen cell suspension, previously incubated with diluted test serum, was incubated at $37^{\circ} \mathrm{C}$ for $1.5 \mathrm{~h}$ with absorbed diluted complement and antilymphocyte serum, serially double-diluted over a range of 1 in $256 \times 10^{3}$ to 1 in $16777 \times 10^{6}$, the total volume of the mixture being $0.4 \mathrm{ml}$. Rosettes were formed by adding $0.1 \mathrm{ml}$ of a suspension of human $\mathrm{RBC}$, centrifuging the mixture at $200 \mathrm{~g}$ for $5 \mathrm{~min}$ then resuspending it gently by rotation. Duplicate aliquots of this suspension were spread on a haemocytometer and the rosettes and lymphocytes counted. The rosette inhibition titre was calculated as the highest dilution of antilymphocyte serum which caused more than a $25 \%$ reduction in the number of rosettes (per 2000 lymphocytes) formed compared with the controls in which the spleen cells were incubated in the absence of antilymphocyte serum. The rosette inhibition titres for a group of negative controls in which preincubation of the lymphocytes was carried out in Hank's Balanced Salt Solution instead of test serum were accumulated during the course of the tests. For convenience, dilutions of antilymphocyte serum have been expressed as $\log _{2}$ (reciprocal dilution $\times 10^{-3}$ ). 
Results

\section{Experiment 1}

The results are shown in Text-fig 1 . The mean titre decreased rapidly after surgery and by $24 \mathrm{~h}$ was indistinguishable from the titres obtained for sera from non-pregnant sheep (Morton $t$ al. 1979) or negative controls $(9.22 \pm 0.83, \mathrm{~N}=9)$. In fact, 1 ewe was assessed as non-pregnant (range $=8-10$ ) $6 \mathrm{~h}$ after surgery, 1 after $8 \mathrm{~h}$ and 1 after $24 \mathrm{~h}$; the fourth had a value of 12 at $24 \mathrm{~h}$ but the 48 -h sample was not available for assay.

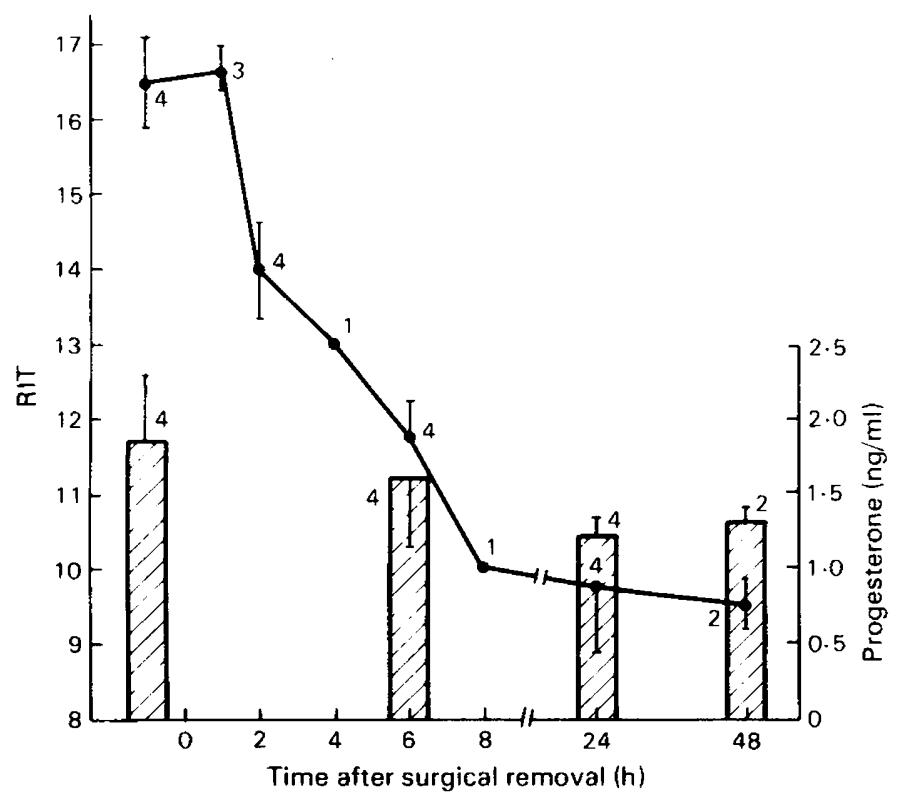

Text-fig. 1. The rosette inhibition titres (O) and progesterone concentrations (hatched columns) of serum samples taken before and at various times after surgical removal of the embryos from ewes 19-20 days pregnant. Values are mean \pm s.e.m. for the numbers indicated. The RIT value for non-pregnant sheep was 8-10.

The progesterone concentrations (Text-fig. 1) indicated that luteolysis had not occurred in any of the animals although a slight overall decrease was observed.

\section{Experiment 2}

A decrease in the rosette inhibition titre from $18.33 \pm 1.1$ to $14.50 \pm 1.26$ was evident by $24 \mathrm{~h}$ after cloprostenol injection and all ewes were assessed as being non-pregnant by $48 \mathrm{~h}(9.20$ \pm 0.47 ). The luteolytic response to cloprostenol occurred in all animals with the mean progesterone concentrations declining from $3.96 \pm 0.84 \mathrm{ng} / \mathrm{ml}$ to $0.53 \pm 0.06 \mathrm{ng} / \mathrm{ml}$ over the 2 day period.

Oestrus was detected in all ewes within 3 days of the injection of cloprostenol.

\section{Discussion}

In these experiments, established pregnancies in all 10 sheep were detected at Days 19-21 by the rosette inhibition test. Direct removal of 4 embryos resulted in an immediate (within $2 \mathrm{~h}$ ) decline 
in the rosette inhibition titre, indicating that the amount of 'early pregnancy factor' present in the blood of ewes had also decreased. In individual animals this decline was complete by $6-48 \mathrm{~h}$ after abrupt removal of the embryo. These lower titres (8-10) indicated a state of non-pregnancy as they were similar to values of the negative control group and those reported by Morton et al. (1979) for non-pregnant sheep. Therefore, the rosette inhibition test may be used to monitor embryo mortality within $48 \mathrm{~h}$ of its occurrence.

In untreated experimental animals, or in the field, it would not be expected that the process of death, once initiated, occurs with such rapidity. Therefore, in an attempt to simulate the time course of embryo death in the field, we utilized an indirect method by inducing luteolysis with cloprostenol. At $24 \mathrm{~h}$ after treatment a decline in the rosette inhibition titre was evident but it had not fallen to the non-pregnant range. A comparison of the mean titres for this group with those shown for Exp. 1 (Text-fig. 1) indicates that embryo death occurred about 2-4 h before the 24-h sampling time. All ewes were assessed as being non-pregnant by $48 \mathrm{~h}$ and they experienced oestrus within another $24 \mathrm{~h}$. These observations confirm our preliminary work in sheep and cattle (Evison, Nancarrow, Morton, Scaramuzzi \& Clunie, 1977; Nancarrow et al., 1978) and demonstrate that embryo mortality in the field can be identified conclusively by testing serum taken $48 \mathrm{~h}$ after the death of the embryo. Whether this will also be possible at stages of pregnancy later than 21 days remains to be determined, but as the rosette inhibition test still signifies pregnancy in most sheep at 2-3 months gestation $(\mathbf{H}$. Morton, personal communication), and in mice until 4-6 days before term (Morton, Hegh \& Clunie, 1976) it is quite likely that this test could be used for sheep at more advanced stages of pregnancy. This test could also be used to detect embryo failure which occurs before Day 12 and is not accompanied by extended cycle length, thus contributing to an underestimation of mortality (Edey, 1969). However, the rosette inhibition test at present depends on a supply of donor animals to provide lymphocytes and its throughput of samples is low (2-4 per day). Therefore, a simpler method for assaying the 'early pregnancy factor' must be devised.

Two proteins which cause depression of lymphocyte activity during pregnancy in the mouse have been described (Clarke, Morton \& Clunie, 1978). The first appears soon after fertilization (molecular weight $\simeq 180000$ ) while the second $(\simeq 40000)$ appears later and may be analogous to human chorionic gonadotrophin. In the sheep, a high activity of 'early pregnancy factor' is detectable 1 day after mating (Morton et al., 1979) and may act to protect the fertilized ovum from immunological rejection by modifying the activity of maternal lymphocytes. If the sheep proves analogous to the mouse, then the factor(s) we are titrating at Days 19-21 may consist of the 'early pregnancy factor' plus other trophoblastic factors, such as ovine placental lactogen. If this were so, then assay methods based on suppression of lymphocyte function may possibly be devised to detect this and other pregnancy-associated proteins in early pregnancy.

We acknowledge the gifts of antilymphocyte serum from Ms H. Morton and cloprostenol from I.C.I., Australia, the able technical assistance of Ms S. M. N. Mariette, and the fruitful discussions with Mr A. L. C. Wallace.

\section{References}

Bach, J.F., Dormont, J., Dardenne, M. \& Balner, H. (1969) In vitro rosette inhibition by antihuman ALS. Transplantation 8, 265-280.

Bassett, J.M. \& Hinks, N.T. (1969) Microdetermination of corticosteroids in ovine peripheral plasma; effects of venepuncture, corticotrophin, insulin and glucose. J. Endocr. 44, 387-403.

Clarke, F.M., Morton, H. \& Clunie, G.J.A. (1978) Detection and separation of two serum factors responsible for depression of lymphocyte activity in pregnancy. Clin. exp. Immunol. 32, 318-323.
Edey, T.N. (1969) Prenatal mortality in sheep: a review. Anim. Breed. Abstr. 37, 173-190.

Edey, T.N. (1976) Embryo mortality. In Sheep Breeding, pp. 400-410. Eds G. J. Tomes, E. Robertson \& R. J. Lightfoot. W.A. Institute of Technology, Perth.

Evison, B.M., Nancarrow, C.D., Morton, H., Scaramuzzi, R.J. \& Clunie, G.J.A. (1977) Detection of early pregnancy and embryo mortality in sheep by the rosette inhibition test. Theriogenology 8, 157, Abstr. 
Hearnshaw, H., Restall, B.J., Nancarrow, C.D. \& Mattner, P.E. (1974). Synchronization of oestrus in cattle, sheep and goats using a prostaglandin analogue. Proc. Aust. Soc. Anim. Prod. 10, $242-245$.

Morton, H., Hegh, V. \& Clunie, G.J.A. (1976) Studies of the rosette inhibition test in pregnant mice: evidence of immunosuppression? Proc. R. Soc. Lond. B 193, 413-419.

Morton, H., Nancarrow, C.D., Scaramuzzi, R.J., Evison, B.M. \& Clunie, G.J.A. (1979) Detection of early pregnancy in sheep by the rosette inhibition test. $J$. Reprod. Fert. 56, 75-80.
Nancarrow, C.D., Rigby, N.W., Evison, B.M., Wallace, A.L.C., Scaramuzzi, R.J. \& Morton, H. (1978) A pregnancy test used for detection of induced embryo mortality in sheep and cattle. Proc. 6th Asia and Oceania Congress of Endocrinology, Abstr. 115.

Thorburn, G.D. \& Schneider, W. (1972) The progesterone concentration in the plasma of the goat during the oestrous cycle and pregnancy. J. Endocr. 52, 23-36.

Received 8 February 1979 